INTERNATIONAL JOURNAL OF MULTIDISCIPLINARY RESEARCH AND ANALySis

ISSN(print): 2643-9840, ISSN(online): 2643-9875

Volume 04 Issue 11 November 2021

DOI: 10.47191/ijmra/v4-i11-03, Impact Factor: 6.072

Page No.- 1513-1527

\title{
Life Skill-Based Learning Management at State Vocational High School (SMKN) 3 Samarinda
}

\author{
Bere Ali $^{1}$, Dwi Nugroho Hidayanto ${ }^{2}$, Saraka Ali ${ }^{3}$, Hasbi Sjamsir ${ }^{4}$ \\ ${ }^{1,2,3,4} \mathrm{~A}$ senior lecturer at Mulawarman University Samarinda
}

*Corresponding Author: Hasbi Sjamsir

ABSTRACT: This research is based on the following problems: (1) How can life skills-based learning management improve the quality of graduates of SMKN 3 Samarinda? (2) What is the role of motivation in life skill-based learning management at SMKN 3 Samarinda?

The objectives to be achieved are: (1) Describe learning management based on life skills to improve the quality of graduates of SMKN 3 Samarinda. (2) Describe the role of motivation in the management of life skills-based learning of students of SMKN 3 Samarinda. This research uses a descriptive qualitative approach, with the main and first instrument being the researcher himself.

The results obtained in this study indicate that the achievement of life skill-based learning management to improve the quality of graduates cannot stand alone, but it is an integral part of the supporting management. Supporting factors for learning management are: (a) curriculum management, (b) student management, (c) management of educators and education personnel, (d) management of facilities and infrastructure, (d) management of financing (e) management of school and community relations , and (f) Cultural and environmental management. Learning management and 7 (seven) supporting management are carried out by carrying out management functions, namely: (a) Planning, (b) Organizing, (c) Implementation, (d) Control, (e) Monitoring, and (f) Evaluation. With the optimization of the implementation of learning management, it turns out that it can improve the quality of graduates of SMKN 3 Samarinda, namely graduates who have life skills. The successful implementation of learning management and supporting management at SMKN 3 Samarinda is due to the high motivation from all levels of management, educators and educational staff at SMKN 3 Samarinda. High motivation is owned by the ranks of learning management, curriculum management, student management, management of educators and education personnel, financial management, school and community relations management, cultural management and the school environment. Thus, high motivation has a role in realizing learning management based on life skills.

Conclusion: the achievement of learning management is due to the high motivation of all elements of human resources in learning management and support management, namely: curriculum management, student management, management of educators and education personnel, management of facilities and infrastructure, financial management, school relationship management and community, and cultural management and the school environment. Each type of management carries out functions: (a) Planning, (b) Organizing, (c) Implementation, (d) Control, (e) Monitoring, and (f) Evaluation.

KEYWORDS: Learning Management, Motivation, Life Skills.

\section{INTRODUCTION}

Building Indonesian people through the world of education has been explicitly outlined in Law Number 20 of 2003 concerning the National Education System, in article 1, point 1, it reads: "Education is a conscious and planned effort to create an atmosphere of learning and the learning process so that students are actively developing his potential to have religious spiritual strength, selfcontrol, personality, intelligence, noble character, and skills needed by himself, society, nation and state ". The aspirated human is a human with quality both in mind and in body (physically and psychologically), whose manifestation is the responsibility of the world of education, both non-formal, and informal education. 


\section{Life Skill-Based Learning Management at State Vocational High School (SMKN) 3 Samarinda}

Formal education has three levels, namely: primary education, secondary education and higher education. Vocational High School (SMK) is a formal education that provides vocational education at the secondary education level as a continuation of Junior High School (SMP) / MTs or other forms of equivalent or advanced learning outcomes that are recognized as equal / equivalent to SMP / MTs. If you look at the excerpt from Article 1 of Law Number 20 of 2003, then SMK is one type of secondary education that provides skilled students with both basic and secondary skills.

Furthermore, Article 36 paragraph (3) of Law Number 20 in 2003 states: "The curriculum is prepared according to the level of education within the framework of the Unitary State of the Republic of Indonesia by taking into account: a. increased faith and piety; $b$. increase in noble morals; $c$. increase the potential, intelligence, and interest of students; $d$. diversity of regional and environmental potentials; e. demands for regional and national development; f. demands of the world of work; g. development of science, technology, and arts; h. religion; i. dynamics of global development; and J. national unity and national values.

Based on the Regulation of the Director General of Primary and Secondary Education, Ministry of Education and Culture No. 06 / D.D5 / KK / 2018, there are 49 expertise programs organized by SMK. Of the 49 expertise programs, there are 146 skill competencies. In addition, changes in people's tastes, especially millennials, have added to the more basic and middle level skills needed. For example, the development of coffee shops everywhere with hundreds of variations of flavors has become a trend among the young generation.

Currently, we are in the era of technology 4.0 where all sides of life have changed towards digitalization. Its hallmark is automation and acceleration. In the era of digitalization, it is no longer the big that defeats the small, not the strong beating the weak, but the fast beating the slow. Those who are slow will be crushed. The quick one will be the winner. This means that the bearers of vocational mandates, including $S M K$, inevitably have to adapt to the 4.0 era. In business and in industry desperately need skilled workers so that they can continue to adapt to change and progress, there are even in business and in industry that are in the forefront of driving change, but there are also in business and in industry that are stumbling and even dying because they do not able to adapt to change.

Now we have entered the era of VUCA (Volatility, Uncertain, Complexity and Ambiguity). VUCA is a popular term in the business, which describes a business environment that is increasingly volatile, complex and increasing uncertainty. In unstable situations, projecting the future from what happened in the past can actually be misleading if it is used as a reference for decision making. Managers need to respond with an unusual mindset. Skills and knowledge that used to be a mainstay may not be relevant anymore. Managers and workers must be equipped with reskilling and mindset changes in order to be able to compete in the VUCA era.

On various occasions the President of the Republic of Indonesia, Joko Widodo, emphasized the importance of vocational education so that there are young generations who are skilled and ready to work, so that they no longer need to bring in foreign workers. Thus income increases and poverty can be gradually overcome. Related to this, the Director General of Vocational Education (Dirjen Diksi) of the Ministry of Education and Culture stated that the facilities and curricula of several SMKs in Indonesia have implemented a link and match with the business and the industry. And this is not inferior when compared to vocational schools in Japan. The most important requirement in $S M K$ is a well-structured curriculum that describes the link and match according to the needs of the business and the industry.

SMKN 3 Samarinda is one of the oldest SMKNs in Samarinda, East Kalimantan because it has been established since 1965. Based on a preliminary study, it is found that this school is quite famous because it is a vocational school that has produced many quality graduates who are able to compete in the business and the industry in East Kalimantan. All of the skills programs that are managed have accreditation A, which is the highest assessment in the management of a skills program in SMK. On that basis, through this research the researcher tries to reveal what kind of learning management is applied at SMKN 3 Samarinda so that it is able to produce graduates who have life skills.

\section{LITERATURE REVIEW}

Management according to (Anggapradja \& Wijaya, 2017) and Mulyono (2014: 16) is the art of retaining, organizing, directing, coordinating, managing resources human and natural power to achieve predetermined learning objectives. The same thing was stated by (Armanu \& Sudjatno, 2017), and (Utomo, Nanere, \& Sutono, 2017) who explain that management is a process of planning, organizing, leadership, control of all organizational resources to achieve the goals set.

According to Gagne (in Anni, et al, 2011: 192) learning is a collection of individual processes, which transform stimuli from a person's environment into a number of information, which in turn can lead to learning outcomes in the form of long-term memory. According to Arifin (2010: 10) learning is a systematic and systemic process or activity that is interactive and 


\section{Life Skill-Based Learning Management at State Vocational High School (SMKN) 3 Samarinda}

communicative between educators / teachers and students, learning resources, and the environment to create conditions that allow student learning to occur..

Good learning management must produce maximum life skills. According to WHO (1997), life skills are skills or abilities to be able to adapt and behave positively, which enable a person to be able to face various demands and challenges in life more effectively. Life skills include five types, namely: (1) self-knowledge skills, (2) thinking skills, (3) social skills, (4) academic skills, and (5) vocational skills. Life skills are self-development to survive, grow and develop, have the ability to communicate and relate either individually, in groups or through systems in dealing with certain situations. Barrie Hopson and Scally (1981) stated that life skills are the interaction of various knowledge and skills so that a person is able to live independently. Meanwhile, Brolin (1989) states that life skills do not only have certain abilities (vocational jobs), but also have basic functional supporting abilities such as: reading, writing and arithmetic, formulating and solving problems, managing resources, working in groups. , and using technology.

Learning planning according to Hartani (2011: 22-23) is thought and determination of things that can be done in the future in order to achieve goals. Meanwhile, according to (Mulyono, 2013: 25) that planning is a process of rational and systematic activities in determining decisions, activities or steps that can be implemented at a later date in order to achieve goals effective and efficient. Meanwhile (Fattah, 2013: 49) suggests that planning is a process of determining unattainable goals or objectives and determining the paths and resources needed to achieve that goal as efficiently and effectively as possible.

Organizing is a process carried out to organize, allocate, and distribute work, authority and resources among members of the organization to achieve organizational goals. This is as stated by Engkoswara \& Aan Komariah (2010: 95), and Didin \& Imam (2012: 129) that organization is an activity to achieve goals carried out by a group of people by dividing tasks, responsibilities, and authority between them, who are the good leaders and actively integrate with each other. Meanwhile, Fattah (2013: 71) describes organization as a process of dividing work into smaller tasks, assigning tasks to people according to their abilities, and allocating resources. , and coordinate it well to achieve goals.

According to (Sudira, 2012) the implementation of learning in vocational education is an effort that moves members and groups to achieve the desired goals. The implementation of learning activities requires the activities of all components, especially teachers and other education personnel so that it can increase the achievement of educational goals effectively and efficiently. This is emphasized again by Didin K \& Imam (2012: 287) that learning is an activity carried out by members and groups of teachers who carry out learning in schools. Learning is the main activity in achieving educational goals as stated by (Kusumawati, 2016). At the SMK level, learning activities aim to encourage the achievement of life skills for students.

Control or supervision is a management function that has an important role. According to Engkoswara \& Komariah (2010: 95) control is a process of monitoring to ensure that learning activities run normally as they should. Furthermore, Didin K \& Imam M (2012: 367) define that supervision is an activity carried out to obtain certainty related to learning. With good control, it is expected that learning activities will run according to the established plan or program. Control is part of the activities carried out by learning management so that learner activities run well.

According to (Khudrin, 2008); (Ariyanti, Sobri, \& Kusumaningrum, 2018), state that monitoring is part of supervision, but monitoring is more specific. By implementing good monitoring, management can reduce obstacles in achieving objectives. Monitoring can also be used to find out changes and conditions that have never been predicted (Fatkuroji, 2015).

According to Suharsimi Arikunto (2003), evaluation is a series of activities aimed at measuring the success of an educational program. Meanwhile, according to Bloom (1971) evaluation is the collection of facts arranged systematically to determine whether there is change in students and to determine the extent to which the level of change occurs in the student's personality.

In the Indonesian Wikipedia, the curriculum is defined as a set of subjects compiled by an educational institution which contains lesson designs that will be given to students in one period of education. According to (Khudrin, 2008), (Fathurrochman, 2017), and (Lubis, 2015) states that the curriculum must be in accordance with the demands and developments of the times. Then (Zulfa \& Pardjono, 2013) stated that in general the management functions of the curriculum include: (1) increasing efficiency in the utilization of curricula resources; (2) increase justice and opportunities for students to achieve maximum results; (3) increasing the relevance and effectiveness of learning according to the needs of students and the surrounding environment; (4) increasing the effectiveness of teacher performance and student activities in achieving learning objectives; (5) increase the effectiveness and efficiency of the teaching and learning process; and (6) increasing community participation to help develop knowledge.

The understanding of student management, among others, was stated by (Subandi, 2020), that student management can be a forum to improve student quality and achievement. Students as raw input need to be managed properly and correctly. The results achieved are not only a manifestation of the success of students but also the success of educational institutions. Student management is an effort to organize students from students entering school to graduating from school. 


\section{Life Skill-Based Learning Management at State Vocational High School (SMKN) 3 Samarinda}

The management of educators and education personnel according to Murni (2017) is an activity that is carried out starting from the teaching and education personnel entering educational organizations until finally stopping through the process of HR planning, recruitment, selection, placement, provision of competencies, awards, education and development training and dismissal. The management of education personnel (teachers and employees) is absolutely necessary for the principal to be able to use them effectively and efficiently to achieve optimal results.

According to (Baehaqi, 2020), educational infrastructure is very important to support improving the quality of education in schools. Infrastructure facilitates the Teaching and Learning Process activities in schools so that they are not hampered (Purwanto, Asbari, Prames-wari, \& Ramdan, 2020). The provision and maintenance of infrastructure in schools is the responsibility of all school stakeholders including the school committee (Gusman, 2020). Facility and infrastructure management includes planning, implementation, control, evaluation and monitoring (Anam, 2019). Meanwhile (Kafarisa \& Kristiawan, 2018) stated that the management of facilities and infrastructure includes increased planning, organizing, actuating, controlling facilities and infrastructure that must be carried out continuously by the education institution.

Education financing management according to (Murniati \& Usman, 2015) is an important thing that must be fulfilled so that all learning activities run smoothly and produce quality graduates. Education financing is the amount of money spent, where does it come from and on whom the money should be spent (Abidin, 2017).

Management of school and community relations is defined as a series of organizational activities or work partners in the context of successful education and teaching processes so that they are right on target according to community needs (Kafarisa \& Kristiawan, 2018). School and community are two inseparable environments, school as a place of learning and community as a place to apply and beautify learning outcomes (Fatkuroji, 2015). According to (Umar, 2016) the principles of public relations are: (a) the principle of authority, (b) the principle of simplicity, (c) the principle of sensitivity, (d) the principle of honesty, (e) the principle of permanence. In addition, there are also several principles used in the administration of school and community relations, namely: (a) Integrity, (b) Continuity, (c) Simplicity, (d) Coverage,(e) Constructiveness (f) Adaptability.

School management must be able to build a culture (habituation) in the personality of students. In this case (L. Hasiara, 2018) in his research observing the management of culture and the school environment: (a) the values of character education based on culture and the school environment; (b) implementation of character education values based on culture and school environment; (c) evaluation of character education based on culture and school environment; and (d) supporting and inhibiting elements of character education based on culture and the school environment. The results of this study indicate that: (a) Cultural values consist of discipline and cleanliness by forming Discipline Driving Students (SPD); (b) the program of conforming student character values is carried out with daily habituation, planning for character values has been designed since the formulation of school activities and plans at the beginning of the year, (c) evaluation of activities is carried out in two activities namely evaluation of activity processes and activity results.

Motivation is a process that begins with a psychological need that gives rise to an impulse with the intention of achieving a goal or incentive. Motivation according to Eggen \& Kauchack (2004) is a force that provides energy, encouragement and directs behavior to a goal. Furthermore, Terry (2006) in Suhaimi, Sjamsir (2019), that motivation is a desire that is found in an individual who stimulates him to take actions. Researchers found there was a high correlation between motivation and achievement (Mc Dermott, et al in Eggen \& Kauchack, 2004).

According to the Broad-Based Education Team (2002), life skills are a person's ability to be willing and brave to face life and life problems naturally without feeling depressed, then proactively and creatively seek and find solutions so that they are able to overcome them (Depdiknas, 2002: 2). According to Anwar (2004: 54), life skills are the abilities needed to interact and adapt to other people, society or the environment in which they are located, among others, skills in making decisions, solving problems, thinking critically, creatively, communicating effectively, fostering relationships between personal, self-awareness, empathetic, coping with emotions, and coping with stress. According to Mawardi (2012: 287), life skills are a continuum of knowledge and abilities that a person needs to function independently in life. According to the Law of the Republic of Indonesia No. 20 of 2003 concerning the National Education System, that life skills education is education that provides personal skills, social skills, intellectual and vocational skills for work or independent business.

\section{RESEARCH METHODOLOGY}

This study describes learning management equipped with supporting management, namely: (1) curriculum management, (2) student management, (3) management of educators and education personnel, (4) management of education financing, (5) management of facilities and infrastructure, (6) management of school and community relations, (7) management of school culture and environment. The description also includes management functions, namely: (a) planning, (b) organizing, (c) 


\section{Life Skill-Based Learning Management at State Vocational High School (SMKN) 3 Samarinda}

implementation, (d) controlling, (e) monitoring, and ( $f$ ) evaluation. Furthermore, it describes the motivation of the Principal, teachers and other education personnel in carrying out their main duties and functions, so that SMKN 3 Samarinda is able to produce quality graduates.

This research was conducted at Vocational High School (SMKN) 3 Samarinda, which is located on Jalan K.H. Wahid Hasyim No. 76 Semarinda. The research method that researcher uses is a descriptive qualitative approach.

The focus is learning management as shown in the following fishbone model image.

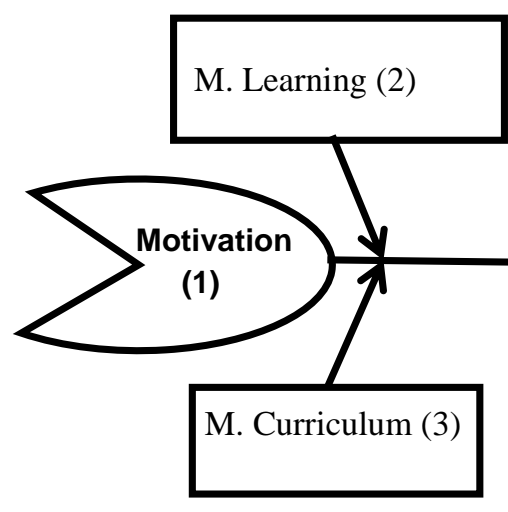

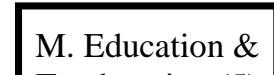

T. educating (5)

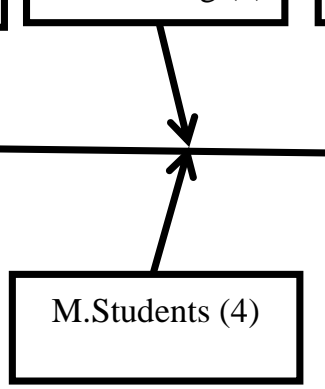

\section{Infrastructure}

(6)

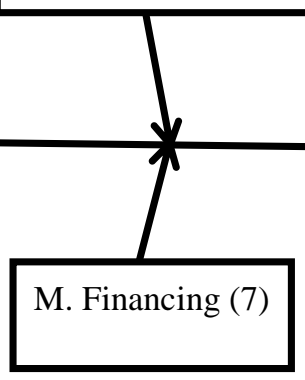

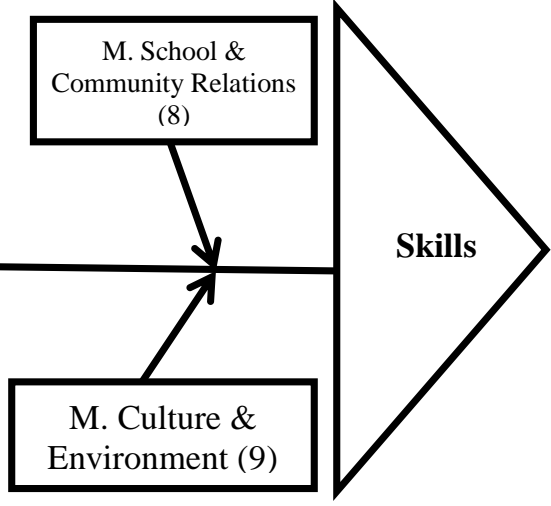

Figure 1. Fishbone Model of Learning Management and Motivation at SMKN 3 Samarinda

The data sources are all elements of leadership at SMKN 3 Samarinda, namely: Principal, Deputy for Curriculum Affairs, Deputy for Student Affairs, Deputy for Facilities and Infrastructure, Deputy for Public Relations, Head of Administration, Head of Laboratory, teachers and other personnel relevant to this research activity.

Data collection techniques and procedures used were observation, interviews, and documentation studies. The three data collection procedures were also supported by triangulation.

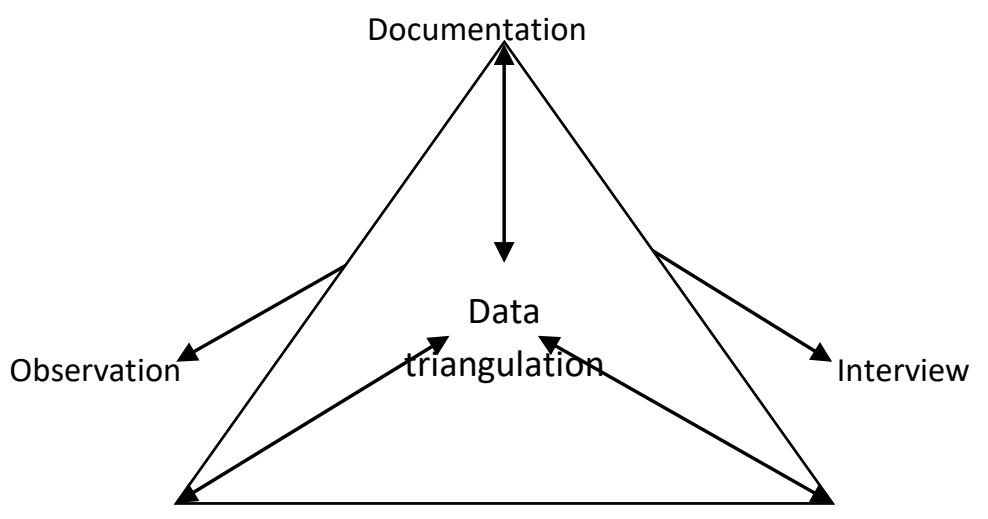

Figure 2. Data Triangulation

Data analysis procedures are: (a) Data Reduction, (b) Data Display (data presentation), (c) Conclusion drawing / verification. Data validity checking procedures are carried out in 4 (four) ways, namely: (1) Trust / credibility, (2) Transferability, (3) Dependability, (4) Confirmability. 


\section{Life Skill-Based Learning Management at State Vocational High School (SMKN) 3 Samarinda}

The stages of this research are as follows

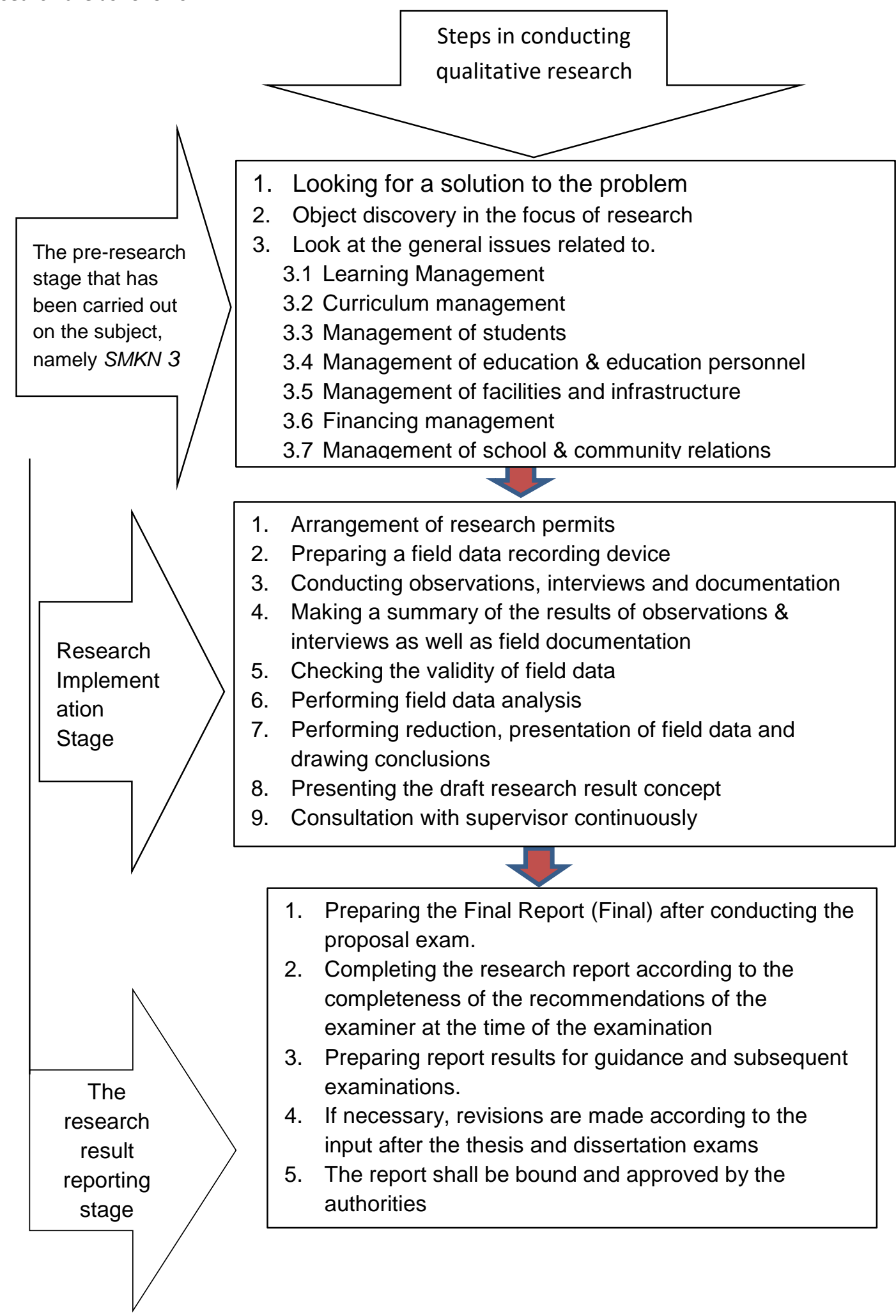

Figure 3. Schematic of Research Stages

\section{RESEARCH RESULTS AND DISCUSSION}

In this study it was found that SMKN 3 Samarinda, founded in 1965, is the oldest SMK in East Kalimantan. It has five Expertise Study Programs, namely: (1) Culinary Expertise Study Program, accreditation A, (2) Department of Fashion Design, accreditation A, (3) Tourism Expertise Study Program, accreditation A, (4) Study Program of Expertise Beauty Administration, accreditation A, and (5) Patisery Expertise Study Program, accreditation A. 


\section{Life Skill-Based Learning Management at State Vocational High School (SMKN) 3 Samarinda}

This school is quite well known in East Kalimantan because all the expertise programs have accredited A. Graduates are of high quality so they have life skills. It is proven that $90 \%$ of graduates are accepted in the world of work, both in government, business and industry, as well as doing business independently.

\section{Learning Management}

Based on the results of interviews with the principal, learning management at SMKN 3 Samarinda has a broad scope because it is supported by curriculum management, student management, management of educators and education personnel, management of facilities and infrastructure, management of education financing, management of school and community relations, and cultural and environmental management. By applying this management, the school's goals, namely life skills (life / skills) can be achieved. All components of school personnel are actively involved in supporting learning management, namely: Principal, Deputy for Curriculum Affairs, Deputy for Student Affairs, Deputy for Facilities and Infrastructure, Deputy for Public Relations, Head of Administration, Head of Study Program, Head of Lab, Counseling Guidance Coordinator, School Committee, Homeroom teacher, teachers, and other education personnel. Educational personnel who also play a role are skilled workers in the business world and the industrial world where students carry out Industrial Work Practices. This is in accordance with the opinion expressed by (Hurley \& Hult, 1998), which states that human resources play an important role in education. HR always plays an active and enthusiastic role in every educational activity (Indrajit \& Djokopranoto, 2006). Every school, both public and vocational schools, always strives to manage human resources in professional ways to improve school performance. In addition, (Hurley \& Hult, 1998), states that what is more important is the emergence of high motivation for education providers.

The implementation of learning management at SMKN 3 Samarinda has been able to produce quality graduates, because it is based on high motivation from all elements in the school. This is in line with the opinion (Rosa, Sukoharsono, \& Saraswati, 2019) that motivation is the strength (energy) of a person who can lead to levels of achievement and enthusiasm at work, both motivations that comes from within the individual himself (intrinsic motivation) and motivation from outside the individual (extrinsic motivation).

The school principal stated that the learning management at SMKN 3 Samarinda had implemented management functions, namely: planning, organizing, implementing, controlling, monitoring, and evaluating. The statement of the Principal is also the same as the statement of all elements of school management, including the Deputy for Curriculum Affairs, Deputy for Facilities and Infrastructure, Deputy for Student Affairs, Deputy for Public Relations, Head of Study Program, Counseling Guidance Coordinator, Head of Lab, Head of Administration, Homeroom, BKK, School Committee and others. This statement is corroborated by observations in schools, where researchers found that learning runs smoothly, both theory and practice (practice in school labs and industrial practice). The results of interviews and observations then the researcher confirms the documentation data that is available in the school properly, for example, the school curriculum book is always adjusted every year, the school organizational structure, new student admission guidelines, guidelines for managing facilities and infrastructure, and so on.

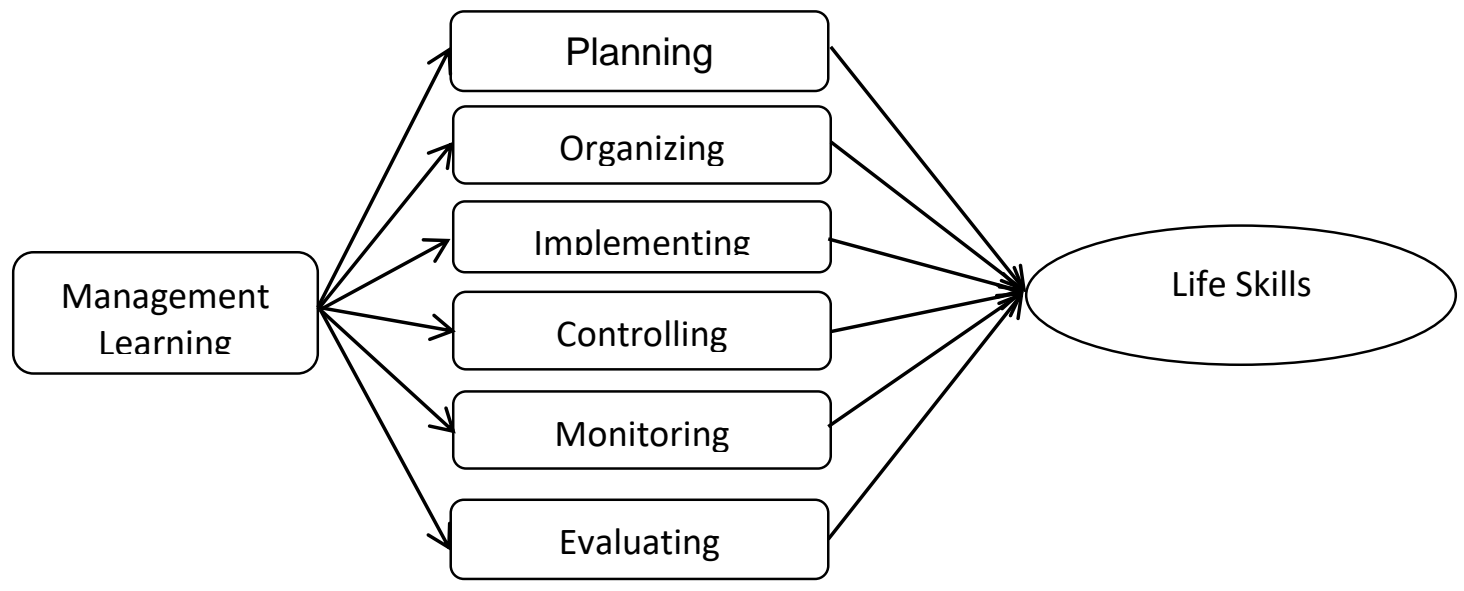

Figure 4. Learning Management Concepts to achieve Life skill

\section{a. Curriculum Management}

The curriculum is a set of tools used to achieve learning objectives. In its implementation, curriculum management at SMKN 3 Samarinda implements six management functions, namely: planning, organizing, implementing, controlling, monitoring and evaluating, which are carried out by the organization to achieve the set goals effectively and efficiently by empowering human 


\section{Life Skill-Based Learning Management at State Vocational High School (SMKN) 3 Samarinda}

resources and other resources. The curriculum at SMKN 3 Samarinda is reviewed every year. The aim is to evaluate whether the curriculum used is still relevant or needs improvement.

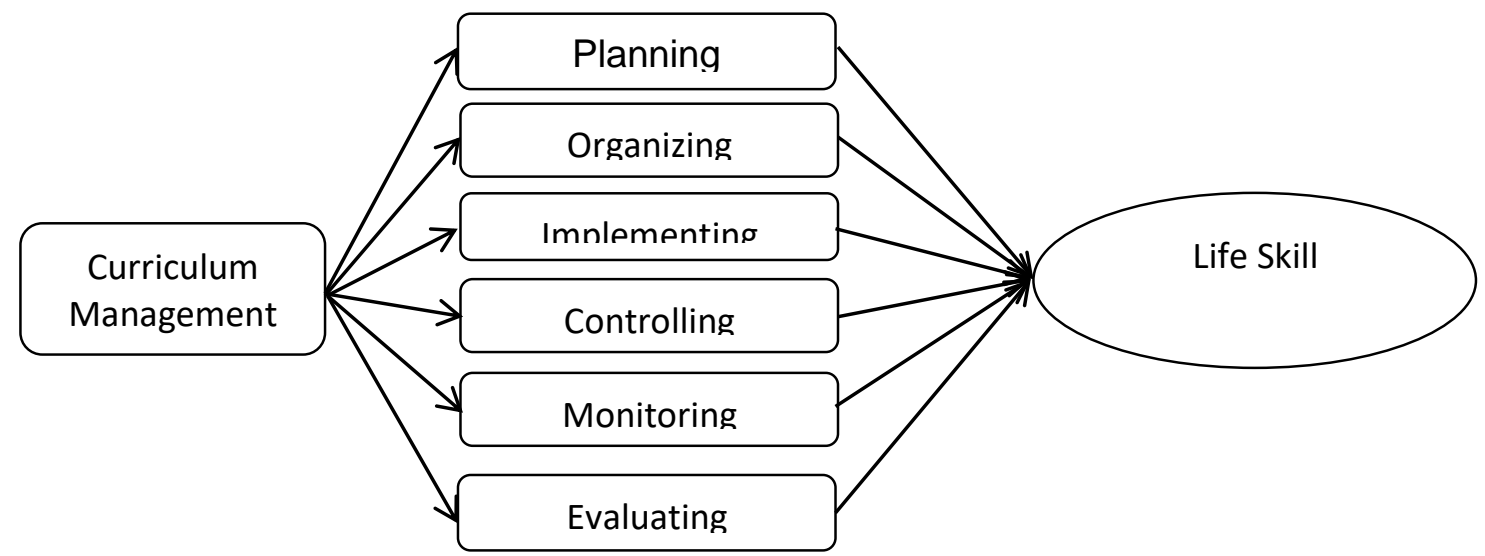

Figure 5. Curriculum Management Concepts to achieve Life Skill

\section{b. Student Management}

Student management is all service activities to students since the admission process until the student has graduated or has moved schools. Student management is an activity that starts from planning, organizing, implementing, controlling, monitoring, and evaluating carried out by the organization to achieve the set goals effectively and efficiently by empowering human resources and other resources.

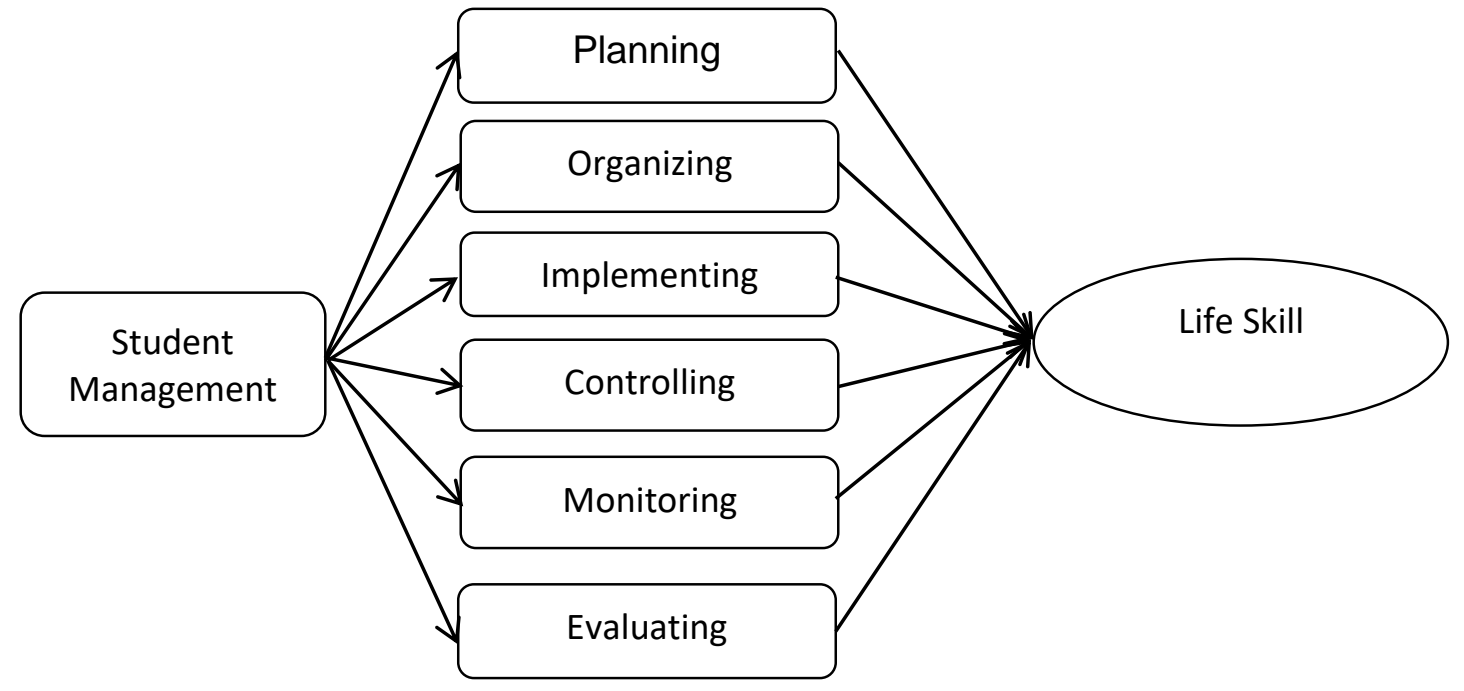

Figure 6. Student Management Concepts to achieve Life Skill

\section{c. Management of Educators and Education Personnel}

The Principal of SMKN 3 Samarinda emphasized that the management of educators and education personnel is an activity that is carried out continuously, starting from planning, organizing, implementing control, monitoring, and evaluation activities carried out by the organization to achieve objectives are set effectively and efficiently. This is in line with the opinion (Suarga, 2019), (Nur, 2009), (Muniroh \& Muhyadi, 2017), and (Aristi \& Hanny, 2014), which states that organizations need to empower human resources and other resources. Learning management at SMKN 3 Samarinda has implemented six management functions. Human resources in schools that play an important role are educators. Educators are educational professionals who are qualified as teachers, lecturers, counselors, tutors, instructors, facilitators and other names in accordance with their specialties which have a strategic role in delivering education. Meanwhile, educational staffs are people who work and work in the field of education including principals, educational unit supervisors, administrative staff, library staff, laboratory personnel, technicians, study group managers, school security and cleaning personnel and others who work in educational institutions. Education personnel are appointed to devote themselves to supporting the implementation of education. 


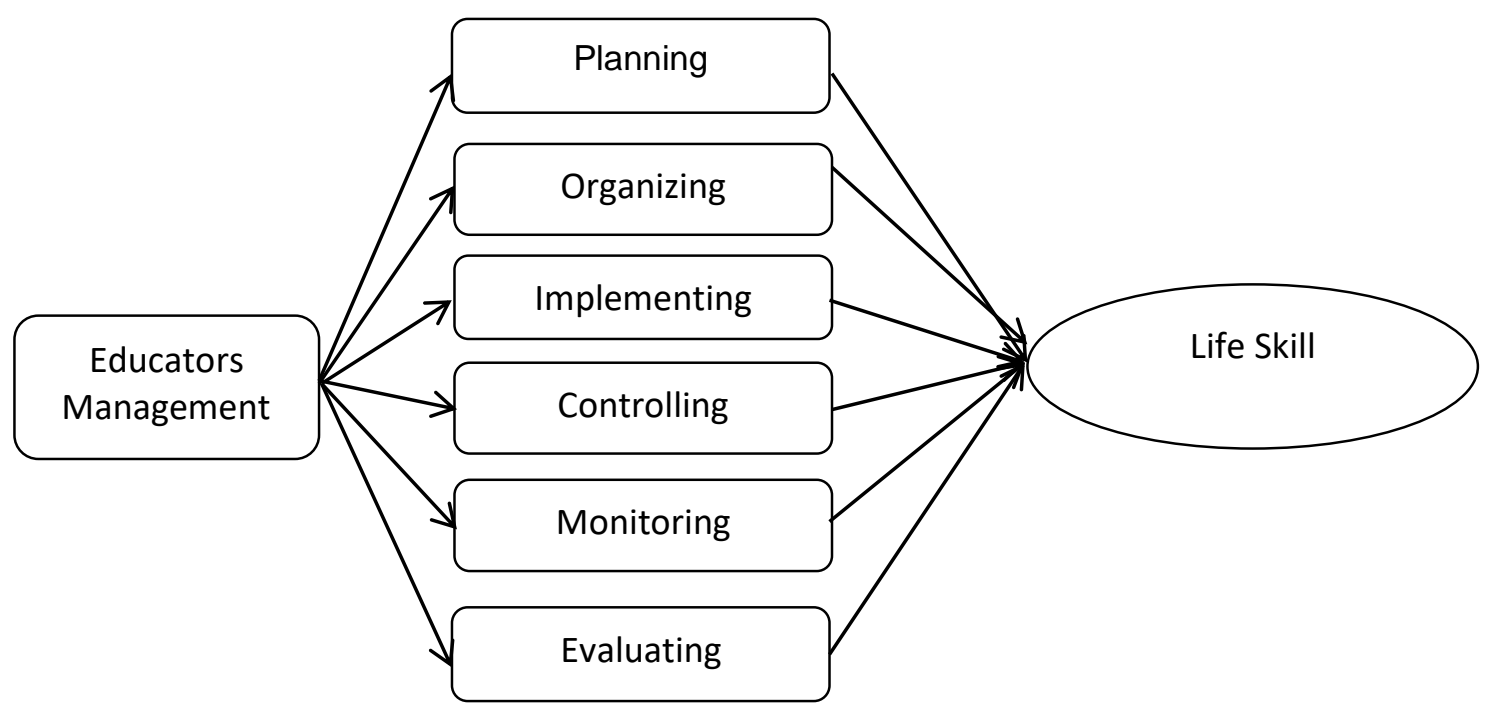

Figure 7. Tendik Management Concept to achieve Life Skill

\section{d. Management of Facilities and Infrastructure}

The School Principal and Deputy for Facilities and Infrastructure stated that the position of facilities and infrastructure in schools was very important in order to support the smooth running of the Teaching and Learning Program. Facility and infrastructure management is an activity starting from the planning, organizing, implementing activities, controlling, monitoring and evaluation processes. Facilities and infrastructure must always be evaluated as stated by (Kurniawati, 2013), and (Megasari, 2014), which explains that the purpose of evaluation is to maintain the continuity of the organization to achieve the goal of using facilities and infrastructure effectively and efficiently. This is also in accordance with the results of the observation / review of all the facilities and infrastructure carried out by the author on July 14, 2020. At the time of this observation the author also saw the relatively complete facilities of hotel rooms, as well as facility and infrastructure of culinary laboratories, beauty cosmetology laboratories, as well as the patiseri laboratory.

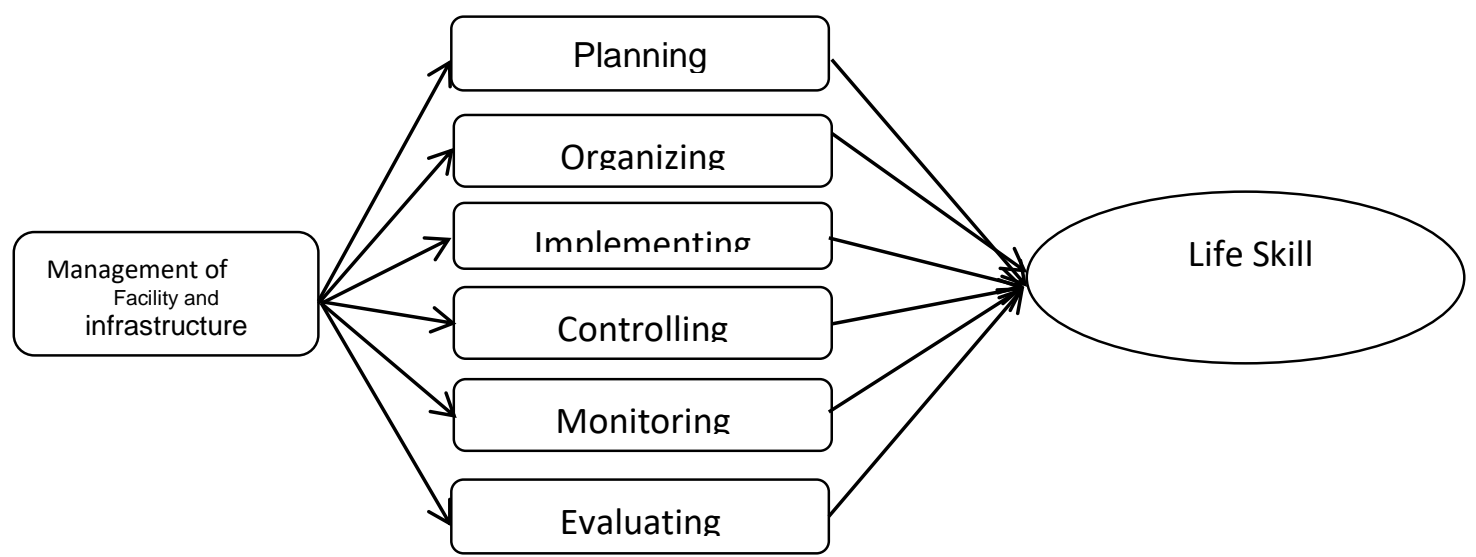

Figure 8. Management Concept of Educational Facilities and Infrastructure to attain Life Skills

\section{e. Education Financing Management}

Implementation of financing management at SMKN 3 Samarinda, has implemented 6 management functions, namely: planning, organizing, implementing, controlling, monitoring, and evaluating. According to (Murniati \& Usman, 2015), (Prayoga \& Risnandi, 2019), and (Abidin, 2017), which states that a management does not stand alone but needs the support of other management elements, financing management is always a priority for managers in managing the organization. This is because money is a limited resource. SMKN 3 Samarinda as a public school receives government budgets in the form of BOSNAS and $B O S D A$. BOSNAS funds are the budget for school operational costs funded by the $A P B N$, while BOSDA comes from APBD funds. The amount of regular BOS funds per SMK student is IDR 1.6 million. Meanwhile, the amount of BOSDA funds in East Kalimantan per student per year for SMK is Rp1,100,0000. Thus, the amount of school operational funds managed by $S M K$ per student per year is IDR 2,600,000. Given the large amount of funds managed, these funds must be planned as well as possible. 


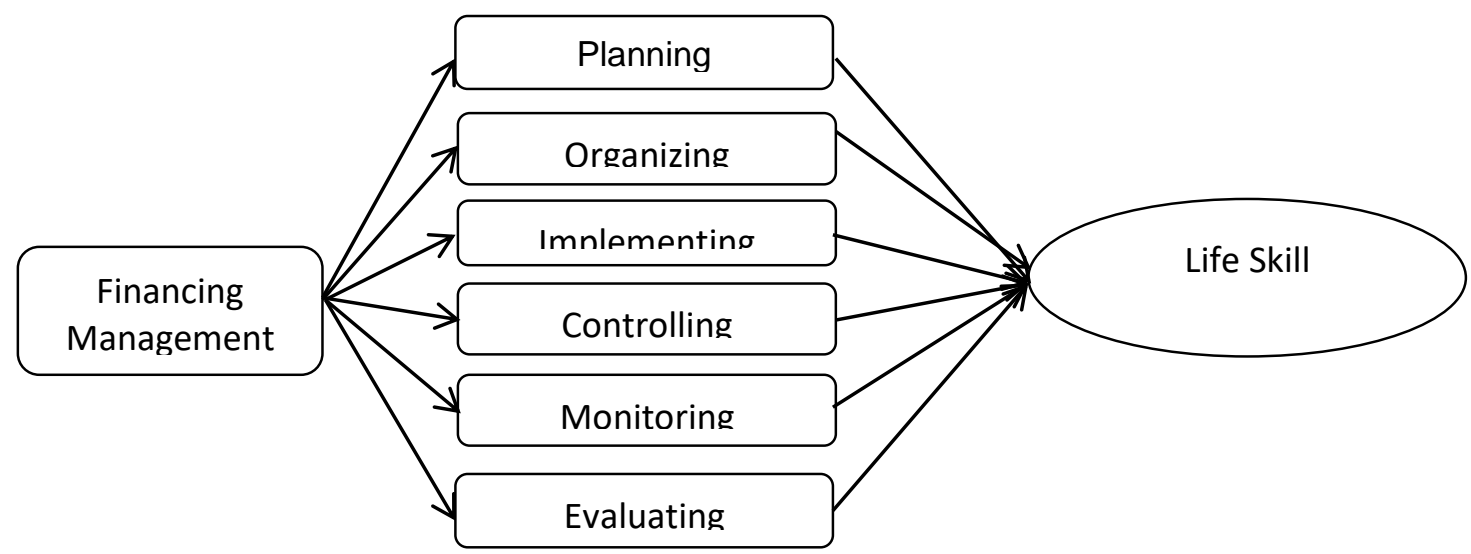

Figure 9. Education Financing Management Concept for Life Skill

\section{f. School Relationship Management and Community}

Observing the explanation given by the Deputy for Public Relation, the relationship between the school and the community, which has been fostered so far, is quite good. This relationship is a reciprocal relationship, that is, relationships that need each other. The same thing was conveyed by (Syari, 2018), (Sabrina, 2014), and (Noor, 2017), and (Wati, 2015), who stated that schools must collaborate with the community. This cooperation is carried out in various forms. The community can help schools, both material and non-material. The management of SMKN 3 Samarinda is fully aware of this, so that they always maintain good relations with the community. Public Relations (PR) is an art of communicating with the public to build mutual understanding, avoiding mistakes and misperceptions. , at once building a positive image for the institution. As a profession, a public relations officer is responsible for providing convincing information, gaining sympathy, and building community encouragement for school improvement. An important part of the work of the public relations officer in an organization is to make a good impression or positive image. Public Relations Management at SMKN 3 Samarinda has implemented functions: planning, organizing, implementing, controlling, monitoring, and evaluating.

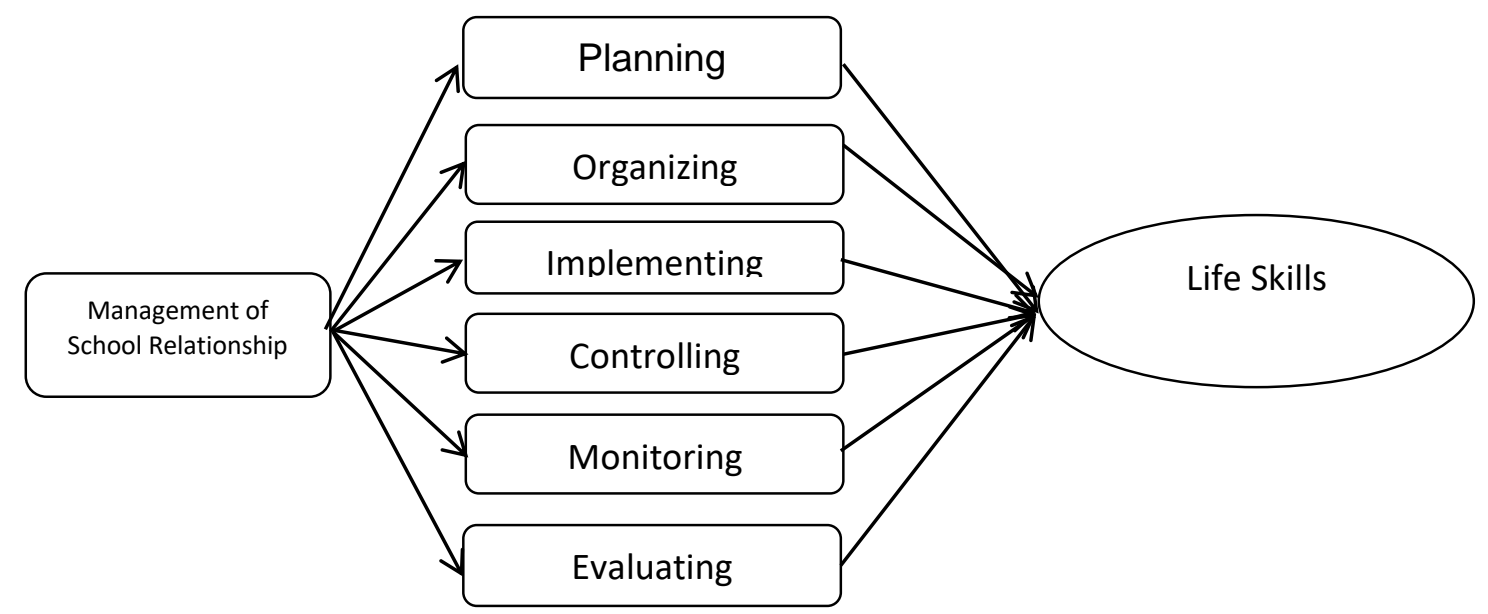

Figure 10. Concept of School and Community Relations Management To achieve Life Skill

\section{g. Cultural Management and School Environment}

Paying attention to the explanation given by the Principal and Student Affairs Representative that culture and the school environment are activities that are carried out continuously to develop the positive character of students. These activities are carried out from one period to the next, to maintain and maintain the synergy of cultural programs and the school environment. Here the school is a place that is conducive to the seeding and development of the character of optimism, developing reasoning, enlightening reason, equipping the skills and attitudes needed to make students who are honest, polite, polite, creative, productive, independent, and beneficial to others. The school environment is one where students interact, in addition to the family and community environment to carry out the socialization process, namely the socialization of values, knowledge, attitudes, and skills. In its implementation, the management of culture and school environment at SMKN 3 Samarinda has implemented the functions of planning, organizing, implementing, controlling, monitoring, and evaluating. 


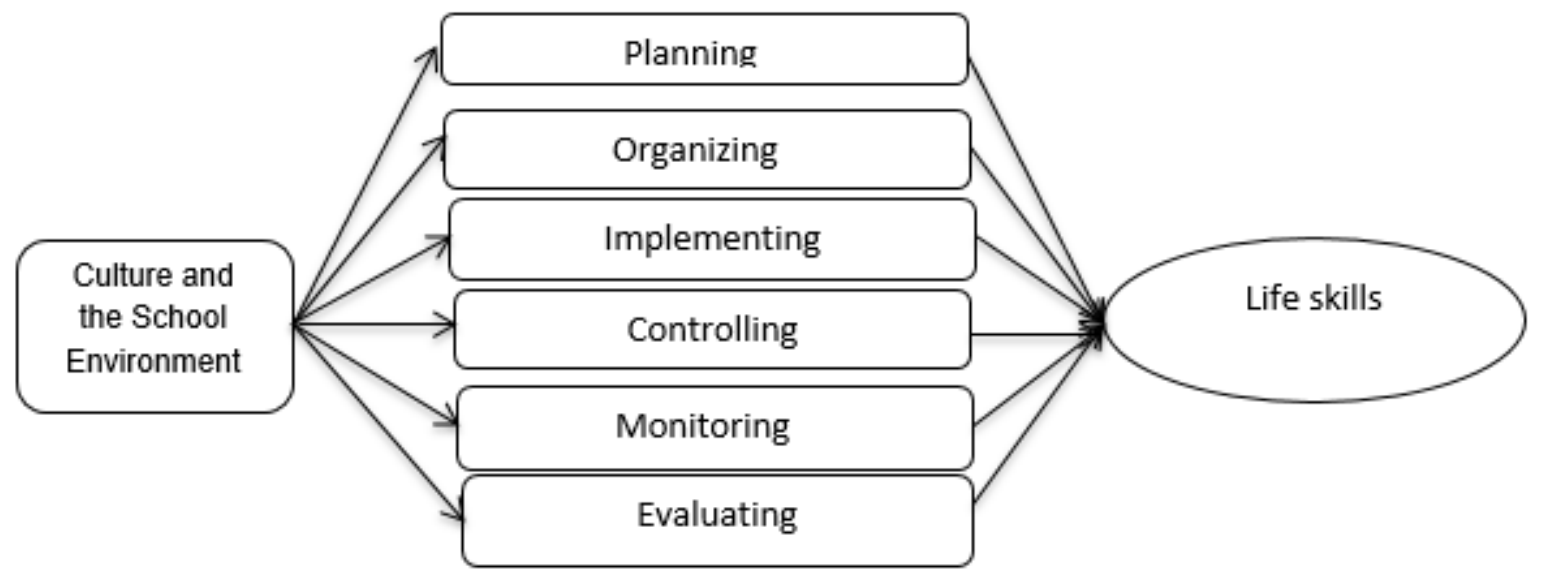

Figure 11. Concept of Cultural Management and School Environment to reach life skill.

\section{Motivation}

The school principal explained that at SMKN 3 Samarinda all elements of management as well as educators and educational staff are serious about carrying out their duties. The tasks assigned to them can be completed according to the targets set. Teaching and Learning Program (PBM) and practice went well. This is because there is responsibility that is based on high motivation. The successful implementation of the Teaching and learning program (PBM) is a manifestation of the performance of all school management parties including: curriculum management, student management, management of educators and education personnel, management of facilities and infrastructure, management of financing, management of school and community relations, and cultural and environmental management. Thus producing students have the expected life skills. Teachers were more visible in their performance in implementing PBM and practice.

In this study, 9 (nine) points were found which motivated the emergence of high motivation for educators and education personnel at SMKN 3 Samarinda, namely: (1) high responsibility for tasks, (2) love of duty, (3) spirit of togetherness / enthusiasm corps, (4) Professional awareness, (5) Love for students, (6) Shame when tasks are not completed, (7) Driven by vision, mission, and school motto, (8) Faith and honesty, (9) Supervision leader.

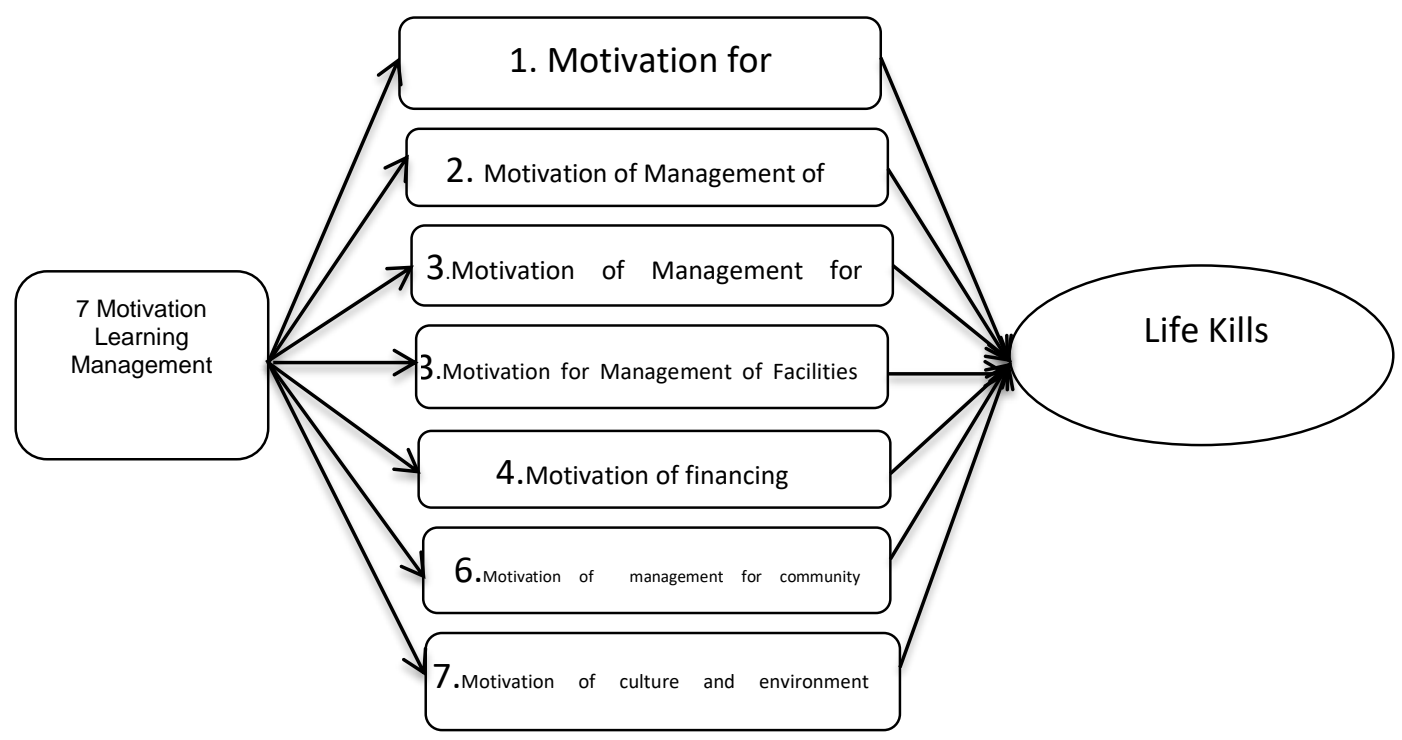

Figure 12. The concept of learning Management motivation to achieve life skill.

The achievement of skills related to learning management is due to the motivation boost in each element of human resources in the school.

\section{Synthesis of Research Findings}

The synthesis of the results of this study can be seen in the following figure 
Life Skill-Based Learning Management at State Vocational High School (SMKN) 3 Samarinda

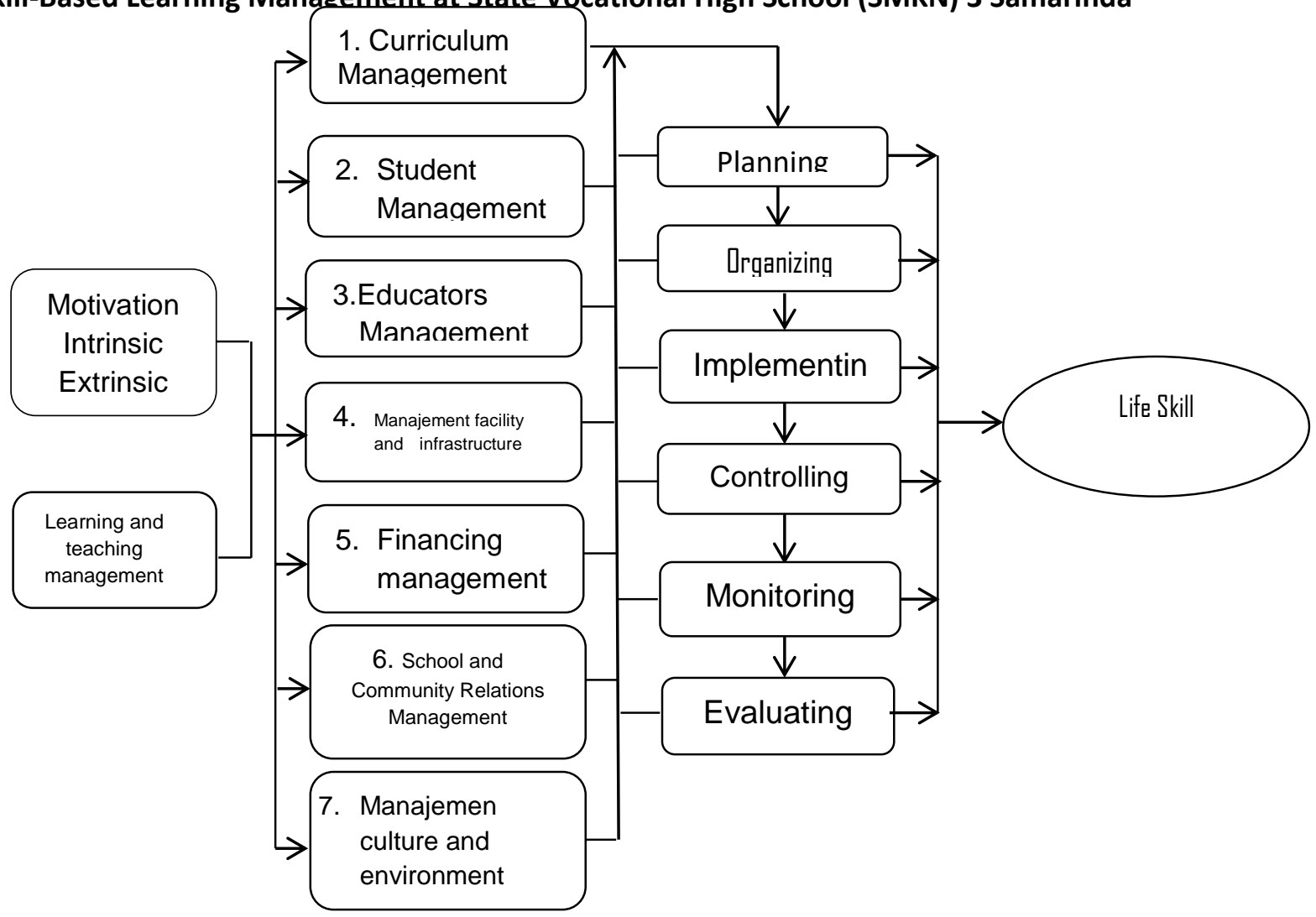

Figure 13. Learning Management Concepts supported by Support Management to streamline life skill.

The picture above is a learning management concept together with motivational elements that are supported by complementary management, and each management implements management functions, so that the expected life skills will be realized.

\section{ACKNOWLEDGMENTS}

Let the authors express their sincere gratitude and appreciation and also thanks to all those who provide the following suggestions and direction.

- Masjaya as a Rector of Mulawarman University, Samarinda, Indonesia.

- Hasbi Sjamsir, as Chair of the Educational Management Doctoral Study Program and as a corresponding author at Samarinda Mulawarman University.

- Dwi Nugroho Hadiyanto and Saraka as the supervisors of the authors

- Last but not least, thank you to all the authors of the articles that I have quoted in our article

\section{CONCLUSION}

Based on the descriptions and discussions that have been stated previously, the conclusions obtained from this study are

1. Life skills - based Learning management is to make the quality of graduates at SMKN 3 Samarinda which can be achieved because learning management is consistently supported by: (a) curriculum management, (b) student management, (c) management of educators and personnel. education, (d) management of facilities and infrastructure, (e) management of financing, ( $f$ ) management of school and community relations, and (g) management of culture and environment.

The effectiveness of learning management and supporting management is carried out by implementing the following functions: (a) Planning, (b) Organizing, (c) Implementing, (d) Controlling, (e) Monitoring, and (f) Evaluating.

2. 2. The successful implementation of learning management at SMKN 3 Samarinda is due to the high motivational role of human resources at all levels of management. The motivation for the human resources at SMKN 3 Samarinda is caused by: (a) high responsibility towards tasks, (b) love of tasks, (c) spirit of togetherness / spirit of the corps, (d) professional awareness, (e) love of students, (f) Driven by the vision, mission, and motto of the school, (g) Shame when the task is not completed, (h) Faith and honesty, (i) Supervision of leaders. 


\section{Life Skill-Based Learning Management at State Vocational High School (SMKN) 3 Samarinda}

Learning Management Based on Life Skills at SMKN 3 Samarinda, formula 2 applies; 7; 6; 1. Or called Management 2 ; 7; 6; 1. Meaning:

$2=(1)$ Learning Management and (2) Motivation

7 = (1) Curriculum management, (2) student management, (5) management of education and education personnel, (4) financing management, (5) management of facilities and infrastructure, (6) management of school and community relations, (7) management of school culture and environment.

6 = (1) Planning, (2) Organizing, (3) Implementing, (4) Controlling, (5) Monitoring, and (6) Evaluating

1 = Life Skill

\section{REFERENCES}

1) Abidin, A. A. (2017). Manajemen pembiayaan pendidikan tinggi dalam upaya peningkatan mutu (Studi kasus pada perguruan tinggi swasta menengah di Surabaya). Jurnal Penjaminan Mutu, 3(1), 87-99.

2) Afrita, I., Imron, A., \& Arifin, I. (2018). Manajemen Hubungan Sekolah dengan Dunia Usaha dan Industri dalam Meningkatkan Prestasi Belajar Peserta Didik Sekolah Menengah Vokasional. JAMP: Jurnal Administrasi dan Manajemen Pendidikan, 1(3), 313-319.

3) Anam, K. (2019). Implementasi manajemen peserta didik dalam meningkatkan prestasi belajar siswa di Madrasah Tsanawiyah Negeri (MTSN) 2 Surabaya. UIN Sunan Ampel Surabaya,

4) Anggapradja, I. T., \& Wijaya, R. (2017). Effect of Commitment Organization, Organizational Culture, and Motivation to Performance of Employees. Jurnal Aplikasi Manajemen, 15(1), 74-80.

5) Ariyanti, N. S., Sobri, A. Y., \& Kusumaningrum, D. E. (2018). Kepemimpinan Kepala Sekolah dalam Meningkatkan Partisipasi Masyarakat. JAMP: Jurnal Administrasi dan Manajemen Pendidikan, 1(1), 1-6.

6) Armanu, A., \& Sudjatno, S. (2017). The Effect of Direct and Indirect Compensation to Motivation and Loyalty of the Employee. Jurnal Aplikasi Manajemen, 15(1), 25-32.

7) Aristi, N \& Hanny, H. (2014). Analisis Beban Kerja Tenaga Pendidikdan Kependidikan di Fakultas Y Universitas X. Jurnal Kajian Komunikasi, 2, (1) Juni 2014 hlm, 53-60.

8) Baehaqi, M. L. (2020). Coorpoerativ Learning Sebagai Strategi Penanaman karakter Dalam Pembelajaran Pendidikan Pancasila dan Kewarga Negaraan di Sekolah. Jurnal Pendidikan Karakter, 10(1).

9) Didin Kurniadin \& Imam Machali. (2013). “Manajemen Pendidikan": Konsep \& Prinsip Pengelolaan Pendidikan. Yogyakarta: Ar-Ruzz Media.

10) Engkoswara \& Aan Komariah. (2010)."Administrasi Pendidikan". Bandung: Alfabeta.

11) Fathurrochman, I. (2017). Implementasi Manajemen Kurikulum Dalam Upaya Meningkatkan Mutu Santri Pondok Pesantren Hidayatullah/Panti Asuhan Anak Soleh Curup. TADBIR: Jurnal Studi Manajemen Pendidikan, 1(1), 85-104.

12) Fatkuroji, F. (2015). Kesiapan pendidik dan tenaga kependidikan dalam menyonsong masyarakat ekonomi ASEAN. ElIdare: Jurnal Manajemen Pendidikan Islam, 1(01), 101-114.

13) Gusman, H. E. (2020). Hubungan gaya kepemimpinan kepala sekolah dengan kinerja guru di SMP N Kecamatan Palembayan Kabupaten Agam. Jurnal Bahana Manajemen Pendidikan, 2(1), 293-301.

14) Hasiara, L. (2018). Penelitian Multi Kasus dan Multi Situs. Penerbit IRDH, Malang Jawa Timur ixxiint, 276.

15) Hasiara, L. O. (2012a). Metode Penelitian Mulit paradigma Satu, membangun Reruntuhan Metode yang Berserahakan. Penerbit Daerkah Media. Malang-Indonesia.

16) Hasiara, L. O. (2012b). Metode Penelitian Multi Paradigma Satu, Membangun Reruntuhan Metde Penelitian yang Berserakan. (1), $x+172$.

17) Hasiara, L. O. S. A. M. D. (2019). Apparatus'Attitude and Behavior, Unqualified Opinion (Opini Wajar Tanpa Pengecualian/WTP), In East Kalimantan Indonesia. Paper presented at the Proceeding Of Medan International Conference Economics and Business Appilied.

18) Hurley, R. F., \& Hult, G. T. M. (1998). Innovation, market orientation, and organizational learning: an integration and empirical examination. The Journal of marketing, 42-54.

19) Ikhwan, A. (2018). Penerapan Manajemen Hubungan Sekolah dan Masyarakat dalam Perspektif Islam. Al-Hayat: Journal of Islamic Education, 2(1), 1-16.

20) Indrajit, R. E., \& Djokopranoto, R. (2006). Manajemen perguruan tinggi modern: Andi.

21) Irfan, M; Bambang, B.W; dan Djum, J.N.B. (2013). Manajemen Pendidikan Jurnal Manajemen Pendidikan, 24, (1), 52-60 


\section{Life Skill-Based Learning Management at State Vocational High School (SMKN) 3 Samarinda}

22) Kafarisa, R. F., \& Kristiawan, M. (2018). Kelas Komunitas Menunjang Terciptanya Karakter Komunikatif Peserta Didik Homeschooling Palembang. JMKSP (Jurnal Manajemen, Kepemimpinan, dan Supervisi Pendidikan), 3(1).

23) Keputusan Bersama Dirjen Pendidikan Dasar dan Menengah Depdikbud RI dan Dirjen Pembinaan Penempatan Tenaga Kerja RI Nomor: 009/C/KEP/U/1994 dan Nomor: KEP.02/BP/1994 tentang Pembentukan Bursa Kerja di Satuan Pendidikan Menengah dan Pemanduan Penyelenggaraan Bursa Kerja.

24) Khudrin, A. (2008). Implementasi Manajemen Kurikulum pada Madrasah Diniyah Al-Aziz Pondok Pesantren Nurul Buda II Kabupaten Sleman DI Yogyakarta. Analisa: Journal of Social Science and Religion, 15(02), 19-34.

25) Kurniawati, P. I., \& Sayuti, S. A. (2013). Manajemen Sarana dan Prasarana di SMK N 1 Kasihan Bantul. Jurnal Akuntabilitas Manajemen Pendidikan, 1(1), 98-108.

26) Kusumawati, D. (2016). Supervisi Akademik Kepala Sekolah Terhadap Manajemen Pembelajaran PAUD. Satya Widya, $32(1), 41-48$.

27) Lubis, A. Y. (2015). Pelaksanaan Manajemen Kurikulum pada SMA Negeri 1 Buengcala Kabupaten Aceh Besar. Jurnal Administrasi Pendidikan: Program Pascasarjana Unsyiah, 3(1).

28) Megasari, R. (2020). Peningkatan pengelolaan sarana dan prasarana pendidikan untuk meningkatan kualitas pembelajaran di SMPN 5 Bukittinggi. Jurnal Bahana Manajemen Pendidikan, 2(1), 636-648.

29) Muniroh, J \& Muhyadi. (2017). Manajemen Pendidik Dan Tenaga Kependidikan di Madrasah Aliyah Negeri Kota Yogyakarta. Jurnal Akuntabilitas Manajemen Pendidikan, 5 (2) September 2017, 161-173.

30) Mulyono. (2013). “Manajemen Administrasi \& Organisasi Pendidikan”. Yogyakarta: Ar-ruzz Media.

31) Murni, M. (2019a). Konsep Manajemen Humas pada Lembaga Pendidikan Islam. Intelektualita, 5(1).

32) Murni, M. (2019b). Manajemen Tenaga Pendidik dan Kependidikan. Intelektualita, 5(02).

33) Murniati, A., \& Usman, N. (2015). Manajemen Pembiayaan pendidikan dalam Meningkatkan Mutu Pembelajaran pada MTsN Janarata Kecamatan Bandar Kabupaten Bener Meriah. Jurnal Administrasi Pendidikan: Program Pascasarjana Unsyiah, 3(4).

34) Nafisah, D; Widiyanto; Wijang, Sakitri. (2017). Manajemen Pembiayaan. Jurnal Economic Education Analysis,6 (3), Oktober 2017.

35) Nanang Fattah. (2013). “Landasan Manajemen Pendidikan”. Bandung: Remaja Rosdakarya.

36) Noor, M. (2017). Manajemen hubungan sekolah dan masyarakat (humas) di Sekolah Dasar Islam Terpadu (SDIT) Sahabat Alam Palangka Raya. IAIN Palangka Raya,

37) Nurabadi, A. (2018).Pendidikan Karakter Berbasis Budaya Dan Lingkungan Sekolah. JMSP (Jurnal Manajemen dan Supervisi Pendidikan), 3 (2)

38) Maret 2019

39) Nur, A. (2009). Pendidik Dan Tenaga Kependidikan. Jurnal Meditek, 1 (2) Oktober 2009.

40) Prayoga, A., \& Risnandi, A. (2019). Manajemen Pembiayaan Pendidikan Madrasah Aliyah Darusalam Sumedang. Cakrawala: Jurnal Manajemen Pendidikan Islam dan Studi Sosial, 3(2), 117-131.

41) Purwanto, A., Asbari, M., Prameswari, M., \& Ramdan, M. (2020). Gaya Kepemimpinan di Madrasah Aliah Autentic, Transformational,Authoriatarian atau Transactioanl? Nidhomul Haq: Jurnal Manajemen Pendidikan Islam, 5(1), 15-31.

42) Rosa, M. C. W., Sukoharsono, E. G., \& Saraswati, E. (2019). The Role of Venture Capital on Start-up Business Development in Indonesia. Journal of Accounting and Investment, 20(1), 55-74.

43) Sabrina, S. (2020). Pengelolaan Hubungan Sekolah Dengan Masyarakat (Husemas) Di Sma Negeri $12 \times 11$ Enam Lingkung Kabupaten Padang Pariaman. Jurnal Bahana Manajemen Pendidikan, 2(1), 689-695.

44) Syari, I.A; Ali Imran \& Imron Arifin. (2018). Manajemen Hubungan Sekolah Dengan Dunia Usaha Dan Industri Dalam Meningkatkan Prestasi Belajar Peserta Didik Sekolah Menengah Vokasional, 1(3), 313-319.

45) Suarga. (2019). Tugas Dan Fungsi Manajemen Pendidik dan Tenaga Kependidikan. Jurnal Idarah, 3 (1), Juni 2019.

46) Subandi, S. (2020). Promosi Jabatan, Mutasi, Dan Motivasi Berprestasi Sebagai Upaya Meningkatkan Prestasi Kerja Aparatur Sipil Negara. REVITALISASI, 8(1), 118-128.

47) Suhaimi, S., Akbar, M., \& Sjamsir, H. (2019). Pedagogic competence effect, attitude on profession, and motivation to the teacher performance. ljer - indonesian journal of educational review, 5(2). Retrieved from http://journal.unj.ac.id/unj/index.php/ijer/article/view/12463

48) Undang-Undang RI Nomor 20 Tahun 2003 "Tentang Sistem Pendidikan Nasional".

49) Umar, M. (2016). Manajemen Hubungan Sekolah Dan Masyarakat Dalam Pendidikan. Jurnal Edukasi: Jurnal Bimbingan Konseling, 2(1), 18-29. 


\section{Life Skill-Based Learning Management at State Vocational High School (SMKN) 3 Samarinda}

50) Utomo, J., Nanere, M., \& Sutono, S. (2017). The effect achievement motivation, leadership character and internal culture towards employee's performance a case corporate from Indonesia. Jurnal Aplikasi Manajemen, 15(1), 1-9.

51) Wati, E. (2015). Manajemen Hubungan Sekolah Dan Masyarakat. Jurnal Manajer Pendidikan, 9 (5), 659-664.

52) Zulfa, N. C., \& Pardjono, P. (2013). Manajemen Kurikulum Madrasah Aliah Program Keagamaan MAN 1 Surakarta. Jurnal Akuntabilitas Manajemen Pendidikan, 1(2), 219-234. 